\title{
Differentiated Instruction and Portfolio Assessment: Motivating Young Greek-Romani Students in the English Class
}

\author{
Theodoropoulou Aristea Aikaterini ${ }^{1}, \&$ Zafiri Makrina ${ }^{2}$ \\ ${ }^{1}$ Ministry of Education and Religious Affairs, Greece \\ ${ }^{2}$ Foreign Language Office, Aristotle University of Thessaloniki, Thessaloniki, Greece \\ Correspondence: Theodoropoulou Aristea Aikaterini, Primary school EFL teacher, Ministry of Education and \\ Religious Affairs, Athens, Greece.
}

Received: January 20, 2022

Accepted: February 21, $2022 \quad$ Online Published: March 2, 2022

doi:10.5430/wjel.v12n1p258

URL: https://doi.org/10.5430/wjel.v12n1p258

\begin{abstract}
The socio-cultural changes taking place in Greek classrooms over the last years have rendered the modification and revising of the existing teaching material critical. It is argued that in classes with cultural minorities, students' needs should be put at the forefront, and teaching objectives should be adapted accordingly. The aim of the present study is to investigate the effectiveness of differentiated instruction and alternative assessment in the teaching of English to diverse population classes within a three-month period. The research focuses on the effect these approaches primarily have on triggering students' motivation and, secondarily, on their overall linguistic development. In particular, the study examines the outcomes of two groups of diverse population students attending the third grade of primary school. The experimental group was taught through differentiated instruction, while the control group attended the traditional class. The tools employed were a needs analysis questionnaire, a pre- and post-test, portfolio evaluation checklists and semi-structured interviews. The results of the questionnaires showed students' preference for non-traditional teaching strategies. The findings of the pre- and post-tests revealed that there is a greater progress regarding the skills of the experimental group. However, the statistical analysis (SPSS 26) showed that there are no significant differences. The answers of the portfolio assessment checklists, although scarce, featured the motivating role of portfolios in students' engagement. The results of the semi-structured interviews showed the student's positive overall attitude towards the employed strategies. Nevertheless, the wide attendance outflow, the short research period, the limited sample, as well as the lack of equipment provision suggest more extended future research.
\end{abstract}

Keywords: action research, differentiated instruction, diverse population, portfolios, Romani, young students

\section{Introduction}

The worldwide socio-political changes (UNESCO, 1995) entail serious upheavals in class compositions. The Greek public school is no exception since Greece constitutes the centre of a geopolitical region of great cultural mobility and is the centre of attraction for all those migrant workers, as well as minority groups who wish to work and live in the country. The adaptation of the school's reality to the new needs is considered imperative. Apart from foreign cultures which enrich the students' population, there are also regions in which numerous students originating from cultural minorities attend Greek public schools. Such are the Romani students who are struggling to combine the Greek education, to which they are exposed, with their culture and tradition. According to the Council of Europe (2006), they should be provided with opportunities that will encourage their participation in all educational levels. Their deficient school attendance is considered to be a major problem stemming from their living conditions, their customs, the challenge of the language, as well as the fear of failure (Chatzisavvidis, 2007; Nova-Kaltsouni, 2004; Ploumidi, 2016). Since 1992, several attempts have been realized in Greece, aiming at Romani education and the decrease of drop-out rates (Vasileiadou \& Pavli-Korre, 2011). The results were not successful (Ziomas, Bouzas, \& Spyropoulou, 2011). In 2016, the Greek Ministry of Education announced the implementation of a new European-driven programme for the integration and education of the Roma. The programme includes a five-stage process which entails students' accessibility to school, their integration and efficient attendance, the completion of primary school education, and the provision of specially trained professionals who could offer psychological, financial and technical support.

In addition, measures have been taken for the education of remigrants and immigrants in Greece as well. The Published by Sciedu Press 
massive inflow of people of diverse cultural backgrounds led to the constitution of intercultural education which was an important step but proved to be inadequate in many instances (Trilianos, 2006). In the late 1990's, the Ministry of Education introduced special reception classes operating during the school programme and aimed at offering further help to those students who have difficulty with the Greek language (Damanakis, 2005). However, the remigrants' and immigrants' mother tongues seem to have been neglected by the formal educational policy of Greece (Nikolaou, 2008). Greek schools focus on the development of the Greek language and Greek culture, mainly, dwarfing the existence of cultural and linguistic diversity (Karamitsopoulos, 2016). Consequently, specific measures should be taken so that every student's needs are met and lessons become meaningful.

Meanwhile, according to research, teaching to minorities demands the application of specific strategies. Research conducted by Alexiadou (2019) showed that when dealing with minority groups, the educational policies to be followed are not predetermined. They are shaped and adapted by the interaction with the participants in such a way which will provide equal educational opportunities. Kirkey (2005), in her research, concluded that differentiated instruction (DI) enriched the curriculum and, while focusing on the process rather than the product, it gave students opportunities and motivation to engage in the learning process. Apart from its motivational role, DI could contribute to the improvement of students' progress. In a research study conducted by Mc Adamis (2001), it is evident that the use of DI contributed to both students' enthusiasm and their test-score improvement.

Furthermore, alternative forms of assessment could also play a motivating role regarding students' participation. Research conducted by Nassirdoost and Mall-Amiri (2015) showed that, although portfolios did not affect students' vocabulary progress, they did nevertheless attract their attention to portfolio preparation. Portfolios could also be used as a source of documentation of students' own progress. Tuksinvarajan and Todd (2009) support the importance of portfolios in students' self-monitoring of their learning, as well as in the development of their metacognitive skills.

\section{Literature Review}

\subsection{Differentiated Instruction}

Differentiated Instruction views students individually, suggesting appropriate curriculum adaptations concerning students' diversity (Hall, 2002). It is based on the principle that the instructional approaches should be appropriately adapted according to the students' individuality and diversity (Tomlinson, 2014). Therefore, its application in culturally diverse classes is highly recommended. Through this teaching approach, students are provided a safe environment and fair opportunities to participate and are also given alternatives according to their learning style (ibid.). Tomlinson (1999, p.43), points out that the three fundamental features of DI are "content, process, and product". A purposeful differentiation in content, demands the instruction to be "concept-focused", as well as "principle-driven" (Hall, 2002, p.2). The process may refer to strategies involving high-order thinking, as well as the elements of discovery and reasoning. Additionally, the promotion of students' critical thinking, appropriate activity modification and flexible class management are also parts of the process (Heacox, 2012; Hall, 2002, Bailey \& Williams-Black, 2008). The product is the way a learner demonstrates what knowledge has been acquired and performed over a period of time. A successful product challenges learners' intellect and encourages critical thinking (Tomlinson \& Strictland, 2005; Tomlinson, 2001; Tomlinson, 2005). The affect regards learners' feelings and attitudes towards themselves, their work, and the class. Students' emotions towards learning are affected by factors like gender, learning style, socio-economic and cultural background, and interests (Chapman \& King, 2003).

Later, the scholars suggested the addition of the learning environment as an important element of DI. This concerns both the classroom arrangements, as well as the usual procedures, followed during the lesson (Santangelo \& Tomlinson, 2012).

Strategies used for DI include auditory material, visual aids and kinesthetic tasks (Chapman \& King, 2003). Group work and discovery learning through games are also instances of successful DI strategies. As a result, the creation of a safe and relaxing environment also encourages the positive perception of the learning process (Tomlinson, 1999; Wanja Njangi, 2014)

\subsection{Alternative Assessment}

According to the latest curriculum regarding the teaching of foreign languages in Greece (The Integrated Foreign Languages Curriculum [IFLC], 2016), the traditional assessment method of progress or final exams for learners of the third grade of primary school is not supported since such methods are considered stressful and demotivating. Since the aim of foreign language learning for young learners in Greece is for communication purposes only, assessment should focus on communicative competence which entails the "understanding of sociocultural differences" (Savignon, 2017). Interaction and learner's involvement are needed, thus, self- and peer-assessment are considered fundamental. 
Moreover, providing feedback during the teaching process is necessary, in order to render young students autonomous and responsible for their learning. Alternative approaches come to bridge this gap and challenge traditional assessment changing the governing perception concerning assessment (Reeves, 2000; Tsagari \& West, 2004). Such assessment entails "holistic and learner-oriented assessment" (Vogt \& Froehlich, 2018, p.148), and consequently, the lessons and the assessment should be designed according to the students' interests and needs.

\subsubsection{Portfolios}

According to Apple and Schimo (2004, p.54), portfolios are a "purposeful collection" of work performed by the students; work that is conducted, selected and reflected by the students themselves (Hamp-Lyons \& Condon, 2000). This selection aims, primarily, at exhibiting students' progress in relation to the objectives set (Vogt \& Froehlich, 2018). Portfolios are broadly welcomed by the students' community as they offer an alternative to tests and function as a motivating source. Berrett (2005) discusses the multiple purposes a portfolio may have depending on the context. Authentic and original tasks included in portfolios trigger students' imagination and function in a motivating manner as shown in Martinez-Lirola and Rubio (2009). Motivated students tend to engage in class activities, devote time for developing their metacognitive skills and reach out for help when needed (Jones, 2009). The tasks should be short including visuals, music, and the element of play (Garton, Copland \& Burns, 2010) and they should also aim at students' development (Cameron, 2015). When applying portfolios in the class, students are not confined by strict time limits, as they constitute the core of autonomous learning. Tuksinvarajan and Todd (2009) refer to the fact that portfolios encourage students to document their learning and observe and estimate the strategies used, in order to acquire knowledge. Specially designed checklists could contribute to this idea and facilitate the process of self-monitoring.

\section{The Present Study}

Taking into consideration the Greek school reality and in line with the relevant literature, the researchers designed a series of lessons for the third grade of primary school according to the needs and unique cultural background of the particular group of students. Romani students are a neglected minority group and teaching EFL to such students could be challenging. Weighing this challenge, and in combination with the limited provision of research, concerning EFL teaching to Romani students, further study was met with great interest by the researchers. The purpose of these lessons was to achieve optimal participation and to engage young students in the learning process. Deficient attendance and lack of motivation, on the part of the Romani students, constituted the core of the lessons which were designed to trigger their interest. The study underlines the importance of the instructors-students' strong academic relationship and the application of the appropriate strategies in order to encourage attendance and participation (Burnette, 1999). The teaching/learning process could be accelerated through teacher's understanding of the role of culture as an influential factor (Hartman, 2016).

Lastly, due to the limited availability of research concerning the provision of motivation to young Romani students in English as a foreign language (EFL), this study aims at shedding light on DI and alternative assessment methods and whether these methods of learning and assessment motivate Romani students. Moreover, it attempts to study the provision of stimulus for the development of their language skills, as well as the ways of exploring these different procedures.

To achieve the aim of this research, the present researchers examined the following research questions:

RQ1: Will alternative teaching methods motivate students who are learning English as a foreign language towards the teaching/learning process?

RQ2: To what extent will alternative assessment promote English as a foreign language learning in the classes under scrutiny?

RQ3: Will the students be able to develop all four of their skills?

RQ4: Will differentiated instruction prove to be more efficient for students' progress?

\section{Method}

\subsection{Participants}

The researchers chose to conduct the research in the area of Neoktista, in Aspropyrgos, Attica, and the students who participated in the research were in the $3^{\text {rd }}$ grade of Primary School. The area is outside the city and close to the oil refinery and the rubbish tip. The majority of the population, living in this area, is Romani, while there are also remigrant families from Russia, Albanian immigrants, and a limited number are Greek. The specific specimen regards both male and female students. For the selection of data, the factor which was taken into consideration was 
the homogeneity, between the two groups, in terms of cultural background and population. More specifically, the two classes included a similar number of students. The students were of a similar age range and the groups' synthesis included students of a common cultural background. Additionally, the students' language and cognitive levels were the same; both groups had been taught EFL for two years $\left(1^{\text {st }}\right.$ and $2^{\text {nd }}$ grade) with the focus on their speaking and listening skills. Therefore, at this language level, students were considered able to master new knowledge in the foreign language, while at the same time they were also able to cover previous language learning and educational gaps.

\subsubsection{The Experimental Group}

The experimental group consisted of 18 students attending class G1 of the third grade of the $6^{\text {th }}$ Primary school of Aspropyrgos. As mentioned earlier, the students came from different cultural backgrounds, while there was also diversity regarding their age. The group included 7 boys and 11 girls aged 8 to 11 years old. Regarding their origin, 12 were Romani, 2 came from Russian remigrant families, 1 is a second generation Albanian and 3 are Greeks. The Romani students speak Romani as their mother tongue, the remigrants are bilingual and speak Greek and Russian and the Albanian student's first language (L1) was Albanian and Greek was his second language (L2). Due to the nature of the population, attendance was not stable, and the teachers were obliged to invent ways to attract the students' interest, and improvise in order to encourage attendance and participation. There was also diversity concerning the students' level of competency. Furthermore, the majority of the students came from impoverished families relying on state benefits, and there were also frequent incidents of theft, as well as violence among students. Due to financial problems of the students' families, the lack of materials such as notebooks, pencils and folders was a usual phenomenon. Additionally, Romani students were deprived of stimuli and present difficulty in staying in the class or listening to instructions for long periods of time. Most of the Romani students attended reception classes as well, as they were ignorant of the Greek alphabet.

Under these difficult circumstances, private initiative was of critical importance. As a result, companies and industries operating in the area donated school material to students. There was also an active parents' association struggling to cope with the challenges which emerged. The school participated in volunteer programmes and the students were provided with meals donated by European programmes.

Regarding the school building, the classrooms were prefabricated. There was a lack of basic equipment and the existing equipment was in poor condition. The seating arrangement alternated in order to trigger students' interest and to ensure regular teaching/learning. Consequently, 'horseshoe', group and frontal arrangements were applied according to the needs of the students.

\subsubsection{The Control Group}

The control group was class G2 of the third grade of the $6^{\text {th }}$ Primary School of Aspropyrgos. Regarding learners' background, it was similar to the experimental group, and consisted of 19 students ( 8 boys and 11 girls). The cultural diversity resembled the other group, that is: 15 were Romani, 2 were Albanian, 2 were Russian remigrants and there were no Greek learners. Reception classes were also provided to the Romani students of the control group. Similarities were also observed in the frequency of attendance due to the nature of the population.

\subsection{Instrumentation}

As far as the instrumentation is concerned, the present study featured the following material: NA questionnaires were used for the researchers to identify the experimental group students' perceptions and attitudes towards EFL as well as their preferences with respect to the teaching methods used. Since the study followed a quasi-experimental design, pre- and post-tests were assigned firstly to both groups in order to determine the young students' strengths and weaknesses, and secondly, to monitor any progress made after the intervention. Portfolios were used with the experimental group as a source of motivation, self-monitoring of progress and development of metacognition. After the end of the intervention, semi-structured interviews with the students of the experimental group were realized, so that the researchers could evaluate the extent to which the students were motivated and which aspects contributed to this.

\subsubsection{Needs Analysis Questionnaire}

The process of language learning was not always linear; it involved gradual development and unexpected outcomes (Long, 2005). As a result, curriculum adaptations and designing of special material became integral parts of the teaching/learning process. This required the collection of appropriate information which related to students' attitudes and needs through NA (Richards, 2001). Putting the student in the forefront of teaching and embracing student-centeredness, stakeholders employ tools for the identification of needs, attitudes and perceptions related to 
language learning (Nunan, 1988). Amongst the methods used, the questionnaire exhibits a wide range of benefits. The preparation of a NA questionnaire could be considered easy and the analysis of the information obtained can be realized through simple steps. Additionally, it can also examine numerous issues and the participants can complete it easily (Richards, 2001).

The NA questionnaire designed for the current research was adapted from Tzotzou (2014) and distributed to the experimental group. Due to the participants' low language level and age, the questionnaire consisted of only three short parts, and its completion required approximately 10 minutes. In order to ensure the time needed and the face validity of the tool, the questionnaire was pilot tested with two teachers/colleagues. According to the statistic analysis, the coefficient of alpha-Cronbach is (0.727) which indicates that the questionnaire was reliable and its content valid. Further validity analysis was not suggested, as part A includes dichotomous data and parts B1 and B2 required open-ended questions, and even drawings, consisting of nominal data which could not be computed. Consequently, alpha-Cronbach $\geq(0.7)$ is considered acceptable.

The NA questionnaire was designed following three parameters: students' attitudes towards learning English, their needs and their preferences (Tzotzou, 2014). Through this tool, the specification of the curriculum content was defined and the students' motives were identified. Prior to the completion, there was an introductory note which aimed at informing the students about the purpose of the survey (Taylor- Powel, 1998), however it was also read and explained by the researchers since most of the students were not confident with reading. The questionnaire was primarily written in English and then translated into Greek, so that students could answer the questions avoiding any language proficiency-related anxiety. Furthermore, since the survey was intended for students who face difficulties in reading and writing, the items were presented in tables in which students were required to tick/circle their preference (Tzotzou, 2014) or draw their answer.

In the first part of the questionnaire, the students were asked to give autobiographical information (name, age and class). The second part included three sections. In section A, students were invited to present their attitudes towards the English language by putting a tick in the 'yes/no' column. Section B was divided into two parts focusing on the students' needs. Firstly, the students were given different aspects of EFL (vocabulary, reading, writing, listening, or they could add other according to their opinion) and were asked to circle those which they found the most difficult. Then, a list of different teaching tools (stories, games, songs, films/videos, computers, painting, other) was given and the participants were expected to circle their preferences.

Section C aimed at investigating students' learning preferences. They were expected to write or even draw their answer in a space provided so that the researchers could extract the information needed for the designing of the appropriate teaching material (Tzotzou, 2014). The option of drawing was given due to the fact that there were students who could write neither in Greek nor in English.

\subsubsection{The Pre- and Post-Test}

Pre- and post-tests could diagnose knowledge prior and after the implementation of an approach, and indicate the degree of the improvement accomplished (Dimitrov \& Rumrill, 2003). Pre-tests are used in classes with diverse students to identify problem areas and inefficient teaching methods. Students are not expected to excel in a pre-test. Its main function is diagnostic; it unveils topics that have been conquered or knowledge which still needs further elaboration (Kuehn, 2019). Post-tests are usually identical to the pre-tests which precede and facilitate the teacher to measure the efficiency of a method followed and to provide help to the students who need it the most.

In the particular teaching context, the pre- and post-tests were applied as a means of diagnosing any skills-related progress due to the intervention. The students' level was low and they had never been tested before, therefore, the level of competency was considered pre-A1 (Common European Framework of Reference for Languages [CEFR], 2018). Consequently, it was found appropriate to design a test using the pre-A1 Starters ${ }^{1}$, as its framework. The test included three sections. In the first section, the students were tested on their listening skills; part 1 was a multiple-choice task where students were asked to listen to the teacher reading short, simple dialogues, and were then expected to circle the correct answer. In part 2, the test-takers were asked to listen to a short description and to colour a set of items.

The next section assessed reading and writing skills. Firstly, students were given pictures followed by a word and had to look carefully at each picture and to read the word. If the word was correct, students were asked to tick the box, otherwise they were expected to put an X. Part 2 included a set of pictures with scrambled letters which accompanied the pictures. Students were expected to unscramble the letters and to form words.

${ }^{1}$ University of Cambridge 
The last section of the test was a speaking task. Students were given a picture and were asked simple questions regarding their age and the number of objects in the picture. All the sections included pictures with vivid colours to attract students' interest and encourage motivation (Shabiralyani, Shahzad Hasan, Hamad, \& Iqbal, 2015).

The tests received some validity and reliability measures. After creating the test, ten experts examined its content and face validity. More specifically, eight teachers who taught EFL for more than eight years and two university lecturers who specialised in assessment and testing, studied the tests making appropriate modifications and suggestions in terms of their relevance and clarity. Due to the combination of the cultural background and the linguistic and educational level of the groups under scrutiny, the pilot testing on similar groups of students was not feasible. The reliability of the pre- and post-test was computed through the Cronbach Alpha formula and the values obtained were $(0,796)$ and $(0,77)$ accordingly.

\subsubsection{Portfolios}

The new curriculum promotes alternative methods of assessment as more suitable for young learners. They can also prove to be valuable tools which encourage a stress-free assessment of students' competence and development. In the present study, the use of portfolios was considered ideal to motivate Romani students to acquire a more positive attitude towards learning (Axton, 2012). As Ryan and Deci (2000) put it, intrinsic motivation stems from the appropriate circumstances; students do not have to run into failure but they are responsible for their work, its selection and organization, this was also the case of the experimental group of this research.

Coming to the present research, the students have never previously been assessed in the foreign language. Additionally, the frequency of their class attendance could be characterized as low due to the students' lack of motivation.

Regarding the procedure followed for the application of portfolios, it lasted for about two months during the first school trimester. The steps followed were those defined by Kemp and Toperoff (1998), namely:

1. Teaching goals identification: The main objective of portfolio application was motivation encouragement. However, linguistic competence was not neglected. Skills development was also encouraged through the tasks which were applied in class.

2. Format specification: Each student had his/her own folder decorated according to their taste. According to Georgousis (1990, p.30-36), this promotes a "feeling of ownership", and, more extensively, it engages students in the process

3. Portfolio introduction in class: Students were given information about the process to be followed and the purpose of the application.

4. Content specification: In a new session, the students were presented with the contents to be included in their portfolios. The base of the portfolio format was the ELP ${ }^{1}$ but with several simplifications, thus, rendering it suitable for the students' age, language level and cognitive development. Consequently, it was divided into different sections, namely:

a. Contents page.

b. My Language Passport. Students presented simple personal information about themselves.

c. My Favourite activity. Students attached material regarding an activity performed in class, which they found amusing, followed by a checklist for reflection.

5. Presentation of guidelines: Here, focus was placed on the importance of organization and layout of the portfolios. Students were encouraged to take care of their work. Due to frequent incidents of theft, portfolios were kept safely away, after each session.

6. Notification of other parties: The school principal was informed about the new method to be applied in class and the latter was fully approved. Moreover, a letter of consent was sent to all parents so that they could be informed about the application of portfolios and so that they could give their permission.

7. Preparation period: The time required for the application was demanding. Although it was principally arranged to devote one session per week, more often than not, students wanted to be occupied with their portfolios in order to complete something or to organize them. The teachers who were also the researchers worked as facilitators providing help and feedback when needed.

\footnotetext{
${ }^{1}$ European Language Portfolio 
8. Assessment and feedback: The portfolio entries, selected by the students themselves, were assessed through checklists. Through this process, students were given the opportunity to self-reflect, and to take responsibility of their own learning (McDonald, 2011). The forms were in Greek as the students' English language level would hinder the completion of a form written in the English language. Furthermore, the answers were mainly presented visually, as visuals are considered motivating factors.

Regarding feedback, students were encouraged and advised throughout the process. The objective was to activate students to become engaged in portfolio application. At the end of the set period, the students were nominated with certificates so that they could develop a much-needed feeling of achievement.

Parent-teacher communication was oral as the majority of the parents could not read because they were illiterate. Additionally, this was found to be a more direct and fruitful means of information provision.

\subsubsection{Semi-Structured Interviews}

Semi-structured interviews were also conducted for the realization of data collection. Qualitative methods enabled the current researchers to explore the purpose, the context, and the meaning of the research (Van Teijlingen, 2014). Edwards and Holland (2013) claim that semi-structured interviews are flexible, in the sense that, no structure is required. The researchers created and addressed a set of open-ended questions accompanied by further queries which worked as facilitators (Piercy, 2004).

1. Are you a boy or a girl?

$$
\text { i. boy ii. girl }
$$

2. How old are you?

3. Since when have you been learning English?

4. What is your opinion about the English courses?

5. a. What do you enjoy more?

b. Which activity did you like in particular? Example.

6. Do you have any difficulties?

7. How good are you at writing in English? 1-10.

8 How good are you at reading in English? 1-10.

9. a. Do you listen to, or

b. use English outside school?

10. How would you use the English language in the future?

\section{Would you like something to add?}

These questions allowed the interviewees freedom to talk about whatever they considered as more important, following the general guidelines (Robson, 2005). The semi-structured interview questions were selected in order to diagnose the attitude the young students developed for English language learning after the realization of DI, and to identify the stronger and weaker points of its application. In designing this research method Laforest's guidelines (2009) were taken into consideration. The researchers identified the participants and defined the number of interviewees. The interviews were conducted individually so that the shier or less willing students could participate more eagerly and comfortably.

During the preparation of the interviews the respondents were informed about the process to be followed (Laforest, 2009). In this case, the school principal took cognisance and approved the realization and the recording of the interviews. The students were also fully informed in class, as well as before the interviews, showing great enthusiasm and willingness.

Due to the lack of room availability, all interviews were conducted in the 'Teachers' Office' whenever it was vacant; this resulted in occupying the participants beyond the English language classes. The duration of the interviews did not exceed five minutes for each participant. Regarding the questions, they were asked in Greek so as to avoid intimidating the students and because the language level of the interviewees would not allow a fruitful discussion in English (Cohen, Manion \& Morrison, 2007). 


\subsection{Procedure}

As for the duration and the procedure used, the present research was carried out from October 2019 to January 2020 and required approximately 25 teaching hours. It was quasi-experimental therefore a pre- and post-test design was used for two groups of students (the experimental and the control group). Two third-grade primary school classes participated in the research and were assigned two tests based on the students' age, language and cognitive level. Both groups were given a test prior to the intervention and a post-test. The experimental group was also administered a NA questionnaire in order for the researchers to identify their students' needs and interests and create the appropriate teaching and learning material. The control group was instructed based on the traditional teaching methods proposed by the coursebook, while the researchers designed the lessons addressed to the experimental group in accordance with the DI principles. Portfolio assessment was also applied, as a means of motivating the students. The concluding step was the semi-structured interviews of the young students who attended the experimental group and was performed after the intervention.

\subsubsection{The Lessons}

\subsubsection{Instructing the Control Group}

The control group was instructed mainly through the coursebook 'Magic Book 2' which is distributed to all students in Greece, free of charge. There was no differentiation in teaching but rather 'one-size-fits-all' instruction. The alphabet was presented through pictures followed by rhyming songs. Amusing familiar comic-strip stories were also added, through which the new vocabulary was introduced to the young students and reading was taught but was also integrated with listening to audio material. The Phonics approach facilitated students to familiarize themselves with the Latin alphabet (Scott \& Ytreberg, 1990). The oracy and literacy skills were developed through interesting activities including songs, crafts or dramatizations. All the students were encouraged to participate and further support was more often, than not, necessary.

As far as evaluation is concerned, students were not given any form of test (apart from the pre- and post-tests) and their assessment was based on their overall performance and mainly on their participation and effort. This choice was made because the young learners were not familiar with testing. Additionally, their background with the entailed difficulties, in combination with their deficient attendance, hindered learning, thus, resulting in a low performance. Consequently, failure in a test would probably result in lack of motivation and participation.

\subsubsection{Instructing the Experimental Group}

The lessons for the experimental group were designed in accordance with the NA questionnaire completed by the third graders. Thus, an effort was made to reflect on the students' interests, and the lessons aimed at massive participation. The lessons followed the guidelines of IFLC and were designed in accordance with the objectives set by the textbook. Since the purpose of the lessons was motivation, the tasks follow the principles of DI and included the elements of game and sensory-motor development (Cameron, 2015). Furthermore, task-based learning (TBL) was applied, as the core of the aforementioned process is the student himself/herself, who is encouraged to develop an understanding of language as a tool rather than as a goal (Task Based Learning, 2009). Tasks convert classes into amusing and interesting experiences while students use their language skills at the current level (ibid.).

The English Alphabet was taught through group-work and craftwork, considered to encourage students' motivation and have a positive effect on discipline problems (Case, 2012). Songs and kinesthetic activities were also promoted as main parts of the process. Puppetry was included as a means of communication and motivation regardless of the students' age, language level and cultural background (Peck, 2005). Additionally, puppetry encouraged and promoted the development of imagination and creativity (Marshall, 2013).

From a didactic point of view, the pedagogical value of the application of board-games and computer games was taken into account, in order to create stress-free conditions in which students learn, thus, contributing to better vocabulary enhancement (Mehregan, 2014; Vasileiadou \& Zafiri, 2017).

Finally, dramatization was employed in order to trigger motivation and achieve participation. The use of drama in the EFL class presented multiple benefits (Boudreault, 2010); students developed a sense of confidence and performed better. Additionally, the new vocabulary was fully contextualized and consequently more meaningful (ibid.).

\section{Results}

With regards to the results of the present study, they arose from the data provided by the NA questionnaires, pre- and post-tests, portfolios and semi-structured interviews, which ensured the triangulation of the research and the validity of the study (Guion, Diehl \& McDonald, 2011). 


\subsection{The Needs Analysis Questionnaire Results}

As far as the process of gathering information is concerned, the collected data were divided into three sections according to the parts of the questionnaire distributed. Although the total number of the students who enrolled was 18, only ten students of the experimental group participated in the process. As a result, there was great attendance outflow, something which was noticed in the research conducted by Kazanzi and Zafiri (2019), which also concerned Romani students (of an older age group though).

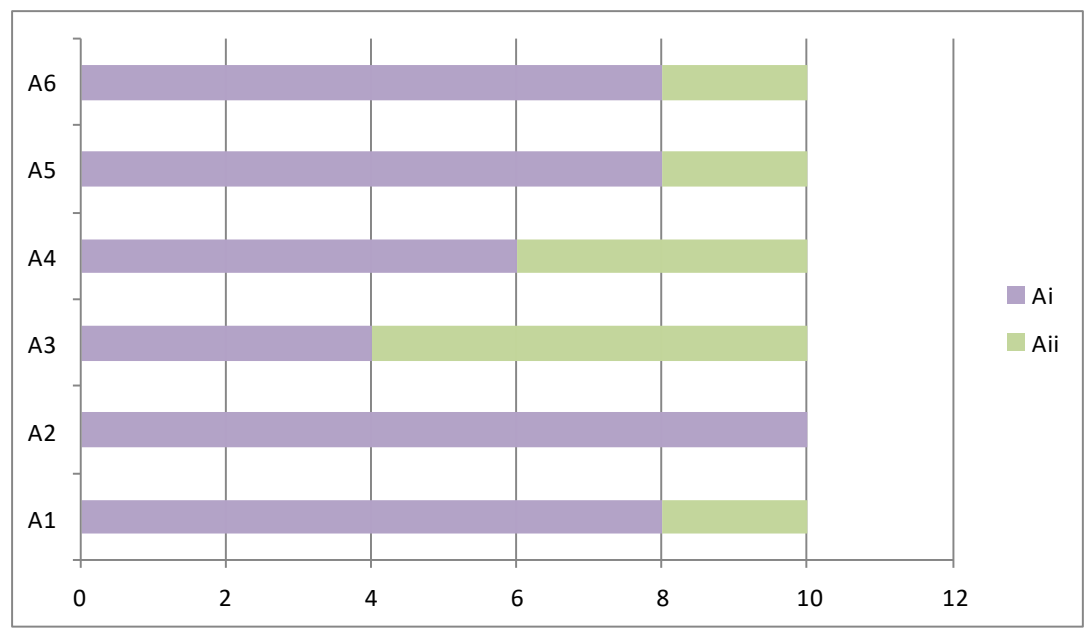

Figure 1. Students' attitudes towards EFL

Part A: As seen in Figure 1, in the first part, the $80 \%$ of the students answered that they like English, and the specimen, in total, showed their preference in using their L1 in class. As far as the difficulty of the target language is concerned, the results portrayed a dichotomy; half of the participants answered that they faced difficulty in learning English, while the other half claimed the opposite. Moreover, the vast majority of the specimen answered that they remembered knowledge acquired in previous years, and most of the students believed that English will prove to be useful for them in the future.

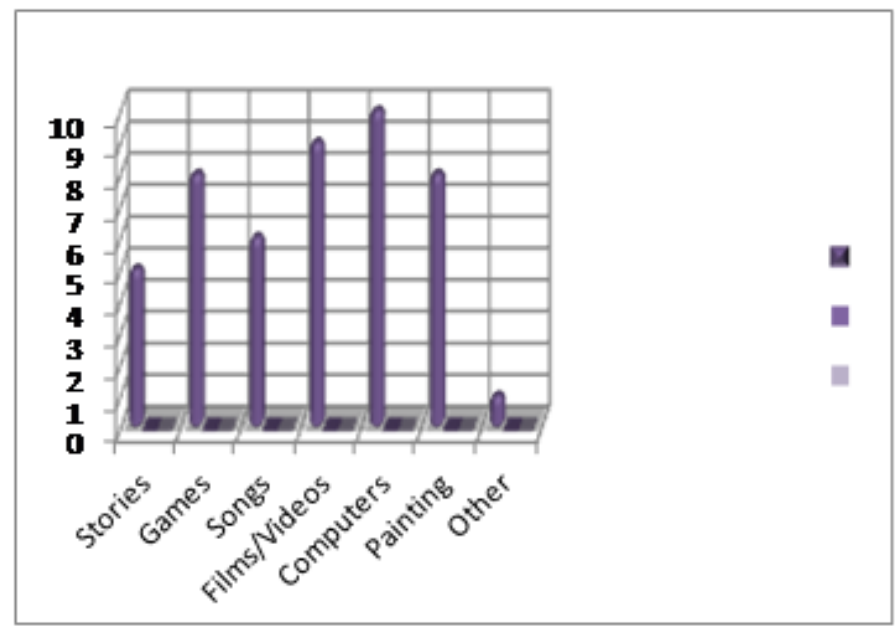

Figure 2. Students' preferences according to the NA questionnaire

Part B: Figure 2 demonstrates that the reading, writing, and listening skills were viewed as equally sophisticated by the young students. Acquisition of new vocabulary was considered to be less difficult, whereas two students commented that none of the fields of EFL were difficult for them. Regarding their preferences on the ways of EFL learning, alternative methods were the most popular. Learning through stories was not as popular as learning with the use of New Technologies, which was met with enthusiasm. Games, songs, videos and painting were also selected, with the 
latter being more preferable. It is worth mentioning that two students also liked writing as a way of learning the foreign language.

Part C: The last part of the questionnaire required the participants to comment, in writing, or through drawings, on what they enjoyed the most in learning English. This question was asked because we wanted the students to express their opinion freely on the particular topic. Many students drew colourful pictures that were irrelevant to the question while others commented that they liked painting with friends.

\subsection{Pre-and Post-Test Results}

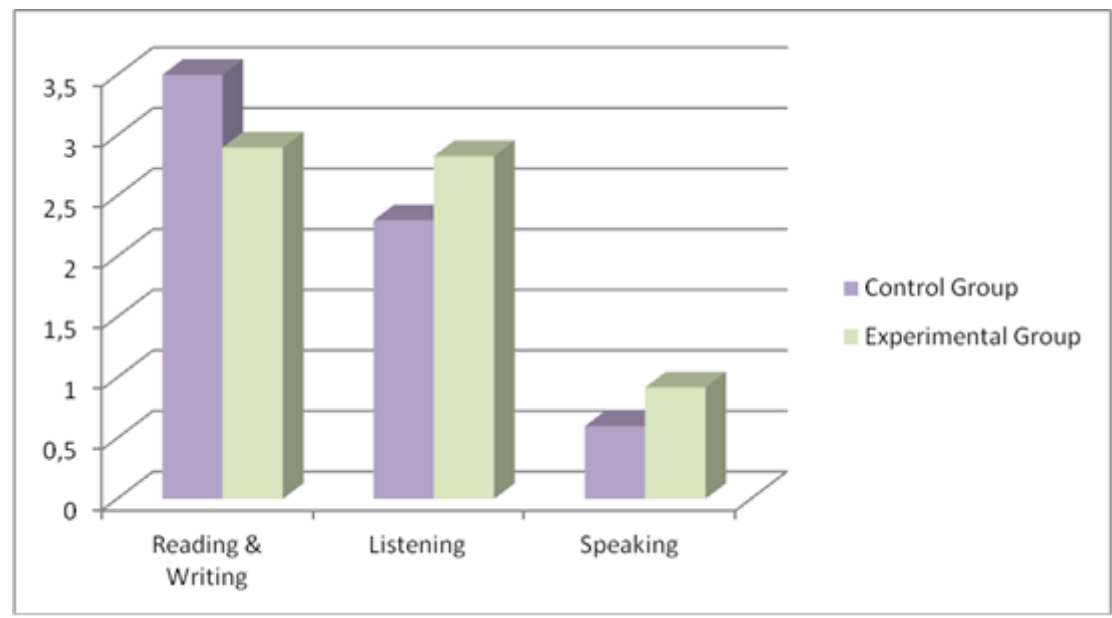

Figure 3. Pre-test results

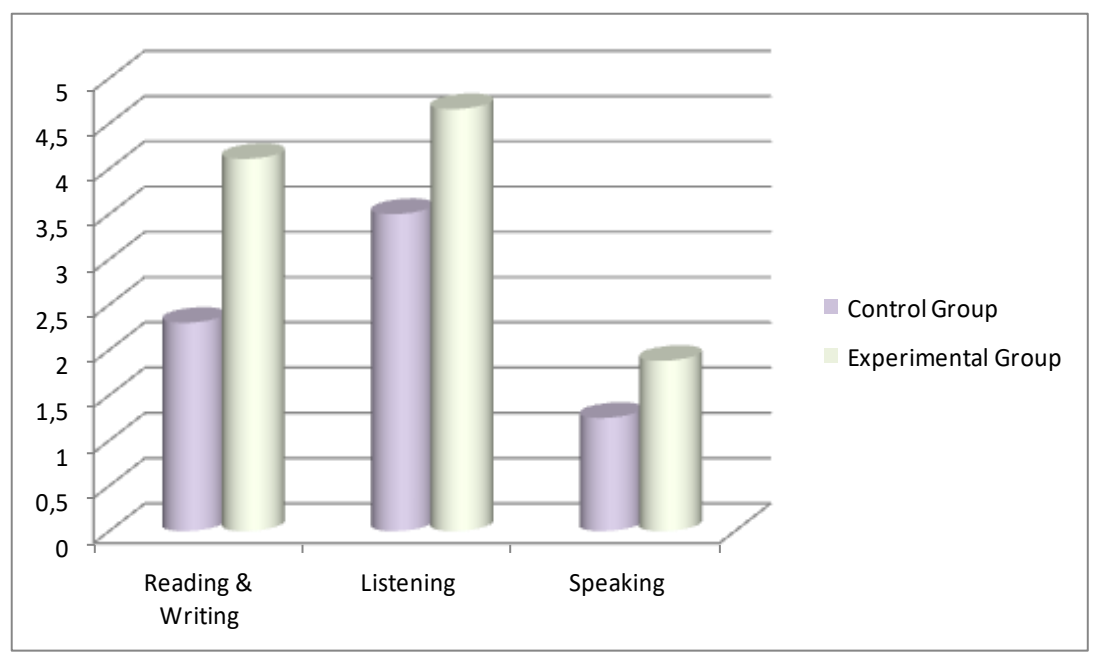

Figure 4. Post-test results

Figure 3 and Figure 4 demonstrate the results of the pre- and post-test of the control and the experimental group. It can be observed that there is an apparent improvement in the post-test scores, especially those regarding the experimental group. However, the statistical analysis showed that this progress was not statistically significant. The data collected were analysed with SPSS 26 software and the method used was independent samples T-test. The aim was to compare two means samples in the pre- and post-test.

Table 1. Mean Score, Standard Deviation and Independent Samples T-test results of the pre-test

\begin{tabular}{|ccccc|}
\hline Group & $\mathrm{M}$ & $\mathrm{SD}$ & $\mathrm{df}$ & $\mathrm{P}$ (Sig. 2-tailed) \\
\hline Control & 5.50 & 4.598 & 14.884 & .558 \\
\hline
\end{tabular}


Table 2. Mean Score, Standard Deviation and Independent Samples T-test results of the post-test

\begin{tabular}{|ccccc|}
\hline Group & $\mathrm{M}$ & SD & df & P (Sig. 2-tailed) \\
\hline Control & 7.13 & 5.222 & 14.302 & .167 \\
\hline Experimental & 10.67 & 4.743 & & \\
\hline
\end{tabular}

Table 1 displays the two groups' overall mean scores in the pre-test as well as the findings of the independent samples T-test. Table 2 presents the two groups' overall mean scores and the relevant T-test findings of the post-test. It is evident that both groups exhibited a higher mean score in the post-test than in the pre-test. Nonetheless, the T-test results indicated that there was no significant difference in skills development regarding both groups. Calculating the significance value of the pre-test, it can be observed that $\mathrm{p}$-value=.558 ( $>\mathrm{a}=.05)$. Accordingly, the $\mathrm{p}$-value of the post-test was .167 (>a-.05). There is a noticeable reduction of the latter p-value if compared to the one of the pre-test. However, the difference between pre- and post-test p-values is considerable and consequently, we need to retain the null hypothesis of no significant differences.

Consequently, the results revealed that the intervention did not drastically impact the experimental group's skills development

\subsection{The Results of the Semi-Structured Interviews}

The final part of the research was consisted with the semi-structured interviews which were conducted with only ten students of the experimental group. The language used was Greek because of the students' English language level and for reasons of motivation. Alshenqeeti (2014) claims that data derived from semi-structured interviews cannot be analyzed through any established method. Creswell (2014) suggests that such an analysis could be feasible if the researcher classified the questions through axial coding; more specifically, the interviewees' experiences could be classified and presented according to their degree of importance and similarity. In the present research, the interviews were transcribed, classified, and studied. The results were coded into three different axes: personal information, attitude towards the target language, perceptions concerning the students' skills and usefulness of the target language in real life.

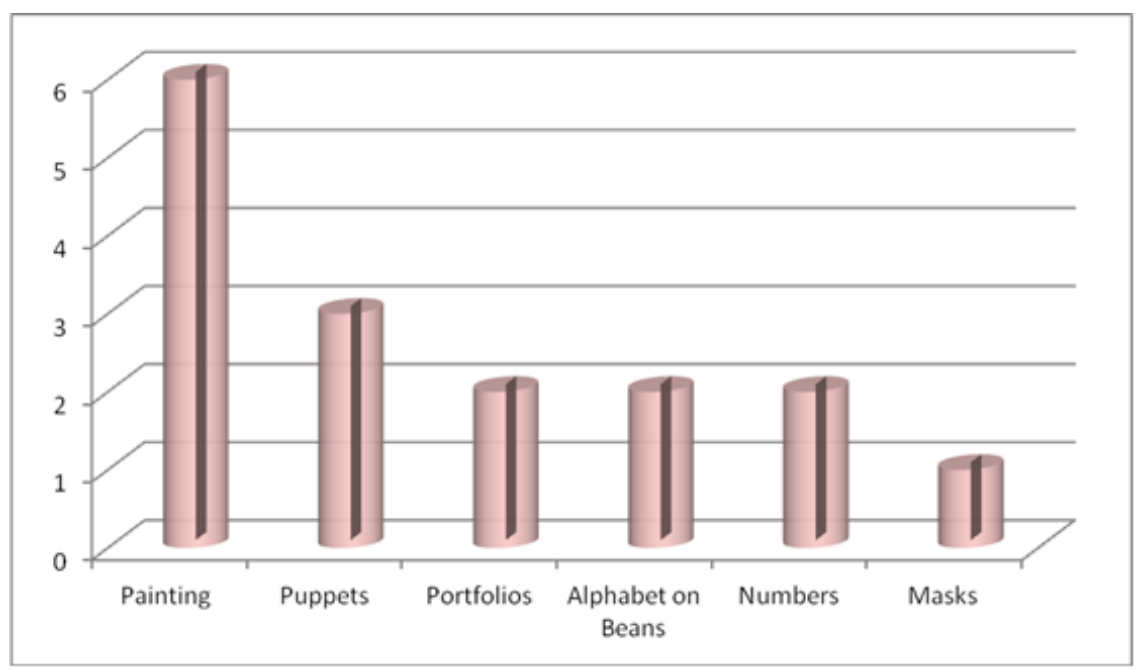

Figure 5. Preferences of the experimental group according to the semi-structured interview

In the first axis, the participants were asked general questions about personal information (Laforest, 2009). The students replied to questions concerning their gender and age, in one word only. According to the answers provided. $60 \%$ of the participants were females and their average age was eight and a half. According to the answers given in the second axis (Figure 5), all the students like learning English; most of the participants enjoyed the fact that they could draw and paint while learning, and others preferred tasks like puppetry. It is worthwhile mentioning that $20 \%$ of the interviewees indicated Portfolios as their favourite part of the lesson, a fact the aforementioned could lead to the assumption that this tool possibly fulfilled its initial goal, namely, motivation. 

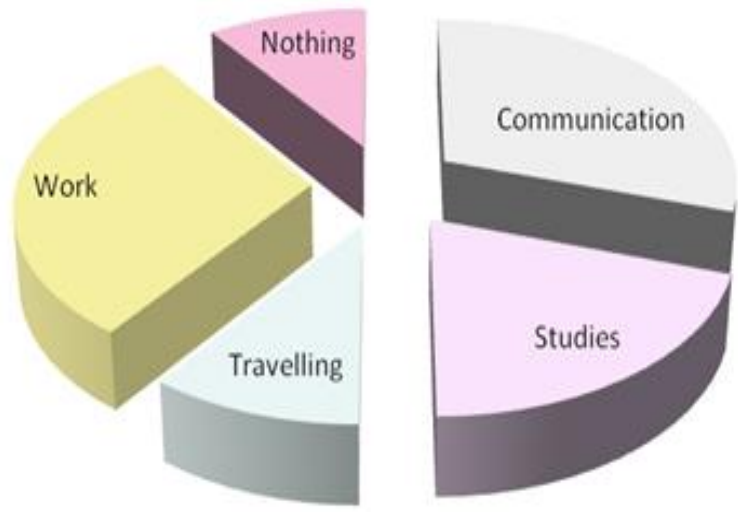

\author{
Communication \\ Studies \\ Travelling \\ Work \\ Nothing
}

Figure 6. Students' perceptions about the future use of the English language according to the semi-structured interview

In the last axis, the majority of the students found that their performance in writing in English was excellent, while $70 \%$ of the participants claimed that their performance in reading was poor. Moreover, most of the students $(70 \%)$ claimed that they use the English language outside the school, especially when listening to music and surfing the Net. The Romani students also answered positively $(80 \%)$ about the future use of the target language, especially when they referred to their future jobs, studies and communication with foreigners (Figure 6).

\title{
5.4 Portfolio Application Results
}

The application of portfolios in the class provided the researchers with qualitative data. However, at the end of the research period the students were handed out a checklist in order to evaluate their portfolios. The design, as well as the content of the checklist was an adaptation from Kemp and Toperoff (1998). All of the students claimed that they had included everything needed in their portfolios. A total of $70 \%$ answered that they had kept their folders organized. The participants, in total, regarded portfolios as motivating tools for learning while $90 \%$ claimed that they were encouraged to engage in the learning process through the use of portfolios. The second part of the checklist included two open-ended questions. Students were expected to comment on the parts of the portfolio they liked and to make suggestions for improvement. The majority of the participants did not provide any answer. From the scarce answers given, the most popular was that the best part of the portfolios was the students' paintings. Regarding further suggestions, students claimed that they would like to include more pages in their folders, which shows that the specific assessment tool encouraged students to participate in the learning process by taking control of the material and the organization of their work.

\section{Discussion}

As for the findings of the present study, it is suggested that the application of DI and portfolio assessment can have a positive effect on the motivation of culturally diverse students, and more specifically on Romani students. Since this cultural group is given stimuli to participate, the results could be encouraging. More specifically, the students of the experimental group exhibited greater interest for the EFL lessons, and attended the classes more regularly. Consequently, the opportunities for participation as well as the creation of a stress-free atmosphere functioned positively (Sougari \& Sifakis, 2007).

In the current study, the teachers/researchers, using a NA questionnaire as a starting point, had designed a series of tasks that included crafts, puppetry, board-games and drama. The young learners welcomed the unprecedented methods with joy and, despite the difficulties arising, the findings portrayed progress. Regarding the findings of the pre- and post-test result, it should be highlighted that skills progress was not the focus of the present study. However, the observation of potential changes in students' progress was found useful. More specifically, although both groups showed similar competency in the pre-test, the post-test revealed an improvement at the skills of the experimental group. The statistical analysis, however, showed that the difference between the pre- and the post-test was not statistically significant, and, therefore, the intervention did not impact the skills of the experimental group in a radical manner. It is indicated that the length of the research period could have affected the results since the intervention was realised in twenty-five teaching hours. 
Coming to portfolio application, young students developed a sense of ownership and did not experience the fear of failure as happens with traditional forms of assessment (Georgousis, 1990; Ryan \& Deci, 2000). Students' autonomy was also promoted since each student was in control of his/her work, a fact which plays a significant role in establishing trust

Bobic (2018), who conducted semi-structured interviews with young Romani learners in Croatia reported that the students (who participated in the research) considered the English lesson useful especially for communication and socialization purposes. This is in line with the findings of the semi-structured interviews of the present study; the students acquired a more positive attitude towards the lessons after the application of DI; they characterized the lessons as more amusing and fun and they were motivated to become involved in the process.

Despite the positive results which emerged from the current study, the analysis of the limitations is also very important. The current research was a small-scale action research which was conducted to a limited sample of the population. According to Dörnyei (2007), the findings of the AR cannot be generalized, a fact that influences the external validity. In addition to this, the validity is also affected by the fact that the population of the research was not stable. Due to the students' cultural background, there was great attendance outflow; the number of students was never stable; there were students who came very rarely and could not keep up with the rest of the class. Nevertheless, certain adaptations were made so that all the learners could participate.

Moreover, another limitation emerging in the current research was the lack of equipment and materials. The school could not provide all the equipment needed. In addition to this, due to the low financial status of the learners' families, there was difficulty in material provision. In order to conduct the research, the researchers had to burden themselves with both finding the appropriate material and the cost of the materials which were needed for the lessons (as for instance folders, markers, materials for puppetry).

It can be concluded that the positive effects of DI application in diverse population classes could foster further research in the field of EFL. Further research is also suggested in terms of Romani EFL students' skills development since in the present study the intervention did not prove to be sufficient. The young students coming from neglected and marginalized social groups need stimuli and new ideas; in order to render the teaching process meaningful, the teaching community should provide the students with fair opportunities and flexible lessons (Raines et al., 2016). To sum up, it is necessary that stakeholders meet the challenge with a fresh mind.

\section{Conclusion}

This study constitutes an action research within which differentiated instruction was applied to diverse population students of the third grade of primary school. In order to examine the effectiveness of the approach followed, the results of two groups of students were elaborated upon, in terms of the progress observed amongst the experimental and the control group. The qualitative, as well as the quantitative data collected, led to the conclusion that differentiated instruction benefitted the students as they exhibited greater interest towards the EFL lessons and appeared more motivated than the students attending traditional classes. However, the findings regard the specific specimen and should not be generalized as they reflect a small-scale research. Moreover, the school attendance of the students under scrutiny was particularly inadequate due to the challenges of their cultural background.

Despite the limitations of the students' cultural identity, their attendance outflow as well as the lack of appropriate equipment, the research experience proved to be fruitful and the positive results rendered it rewarding. The difficulties which emerged provided a challenge which worked constructively and which will be taken into consideration for future improvement.

Further, longer-term research could look into different ways of engaging less-privileged students, as well as provide an opportunity to modify prevailing cultural minority perceptions. Finally, emphasis on the development of young Romani students' language skills could also be examined in a future research.

\section{References}

Alexiadou, N. (2019). Framing education policies and transitions of Roma students in Europe. Comparative Education, 55(3), 422-442. https://doi.org/10.1080/03050068.2019.1619334

Alshenqeeti, H. (2014). Interviewing as a Data Collection Method: A Critical Review. English Linguistic Research, 3(1), 39-45. https://doi.org/10.5430/elr.v3n1p39

Apple, M., \& Schimo, E. (2004). Learners to Teachers: Portfolios, please! Perceptions of Portfolio Assessment in EFL Classrooms, The Interface Between Interlanguage, Pragmatics and Assessment: Proceedings of the $3^{\text {rd }}$ Annual 
JALT Pan-Sig Conference, Tokyo: Tokyo Keizai University. Retrieved from http://hosted.jalt.org/pansig/2004/HTML/AppleShimo.htm

Axton, K. (2012). The Role of Portfolios in Student Motivation, VISIO, 42, 23-42.

Bailey, J. P., \& Williams-Black, T. H. (2008). Differentiated instruction: Three teachers' perspectives. College Reading Association Yearbook, 29, 133-151.

Berrett, H. (2005). White Paper: Researching Electronic Portfolios and Learner Engagement, The REFLECT Initiative. Retrieved from http://google.electronicportfolios.com/reflect/whitepaper.pdf

Bobic, M. (2018). Motivation and Attitudes of Roma Pupils toward Learning English as a Foreign Language (Master's thesis, University of Zagreb, Croatia). Retrieved from http://darhiv.ffzg.unizg.hr/id/eprint/10410/1/Bobi\%C4\%87_Maja_Motivation_and_Attitudes-diplomski\%20rad. pdf

Boudreault, C. (2010). The Benefits of using Drama in ESL/EFL Classroom, The Internet TESL Journal, 16(1). Retrieved from http://iteslj.org/Articles/Boudreault-Drama.html

Burnette, J. (1999). Critical Behaviours and Strategies for Teaching Cultural Diverse Students, Eric Digests. Retrieved from https://files.eric.ed.gov/fulltext/ED435147.pdf

Burns, A. (2010). Doing Action Research in English Language Teaching: A Guide for Practitioners. New York: Routledge. https://doi.org/10.4324/9780203863466

Cameron, L. (2015). Teaching Languages to Young Learners. Cambridge: Cambridge University Press.

Case, A. (2012). Adding Language to Crafts. Retrieved from https://www.englishclub.com/efl/tefl-articles/adding-language-to-crafts/

Chapman, C., \& King, R. (2003). Differentiated Instructional Strategies for Reading in the Content Area. Thousand Oaks, CA: Crowin Press, Inc.

Chatzisavvidis, S. (2007). The Common Roma Language and the Diversity of Gypsy Languages in the Balkans: from the linguistic fiction to the national-genetic ideology. At A. Ph. Christidis (Edit.), Language, Society, History. The Balkans, Thessaloniki: Greek Language Center. (translated from Greek).

Cohen, L., Manion, L., \& Morrison, K. (2007). Research methods in education. London: Routledge. https://doi.org/10.4324/9780203029053

Council of Europe, (2006). Education of Roma children in Europe. Texts and activities of the council of Europe concerning education. Strasbourg: Council of Europe.

Creswell, J. W. (2014). Research design: Qualitative, quantitative and mixed methods approach (4th ed.). SAGE Publications Ltd.

Damanakis, M. (2005). Education of Repatriated and Foreign Students in Greece, Athens: Gutenberg Publishing. (translated from Greek).

Dimitrov, D., \& Rumrill, P. (2003). Pretest-Posttest Design and Measurement of Change, Work, 20(2), 153-65.

Dörnyei, Z. (2007). Research methods in applied linguistics: quantitative, qualitative and mixed methodologies. Oxford: Oxford University Press.

Edwards, R., \& Holland, J. (2013). What is qualitative interviewing? London: Bloomsbury Publishing Plc. https://doi.org/10.5040/9781472545244

Garton, S., Copland, F., \& Burns, A. (2011). Investigating Global Practices in Teaching English to Young Learners, ELT Research Papers 10-01, British Council, Birmingham: Aston University. Retrieved from http://teachingenglish.britishcouncil.org.cn/sites/teacheng/files/B094\%20FINAL\%20Aston\%20University\%20 A4\%20report_2column_V3.pdf

Georgousis, P. 1998. The Portfolio Assessment Tool. Athens: Delphi.

Guion, L., Diehl, D., \& McDonald, D. (2011). Triangulation: Establishing the Validity of Qualitative Studies. University of Florida, IFAS Extension. https://doi.org/10.32473/edis-fy394-2011

Hall, T. (2002). Differentiated Instruction, Wakefield, MA: National Center on Accessing the General Curriculum. Retrieved from http://www.cast.org/publications/ncac/ncac_diffinstruc.html 
Hamp-Lyons, L., \& Condon, W. (2000). Assessing the portfolio: Principles for practice, theory, and research. Cresskill: Hampton Press.

Hartman, H. (2016). Strategies for Teaching Culturally Diverse Learners, New York: RESEARCHGATE. Retrieved from https://www.hetl.org/strategies

Heacox, D. (2012). Differentiated instruction in the regular classroom: How to reach and teach all learners. Minneapolis, MN: Free Spirit Publishing.

Jones, B. (2009). Motivate Students to Engage in Learning: The MUSIC Model of Academic Motivation, International Journal of Teaching and Learning in Higher Education, 21(2), 272-285. Retrieved from https://files.eric.ed.gov/fulltext/EJ899315.pdf

Karamitsopoulos, T. (2016). Educational policy for the heterogeneity and diversity on Greece: a review of the institutional framework. Retrieved from https://eproceedings.epublishing.ekt.gr/index.php/edusc/article/viewFile/248/2 13 (translated from Greek)

Kazantzi, E. F., \& Zafiri, M. (2019). EFL at Greek Second Chance Schools: Examining the Learning Needs of Muslim Adult Learners. World Journal of English Language, 9(2), 74-87. https://doi.org/10.5430/wjel.v9n2p74

Kemp, J., \& Toperoff, D. (1998). Guidelines for portfolio assessment in teaching English, English Inspectorate, Ministry of Education.

Kirkey, T. L. (2005). Differentiated instruction and enrichment opportunities: An action research report. Retrieved from Microsoft Word - 831 - Kirkey_2_.doc (d1wqtxts1xzle7.cloudfront.net)

Kuehn, P. R. (2019). Function and Importance of Pre and Post-Tests. Retrieved from https://owlcation.com/academia/PrePost-Test-A-Diagnostic-Tool-For-More-Effective-Teaching-of-EFL-Student $\mathrm{s}$

Laforest, J. (2009). Guide to Organizing Semi-Structured Interviews with Key Informant, Charting a Course to Safe Living, 1, Quebec.

Long, M. (2005). Second Language Needs Analysis, New York: Cambridge University Press. Retrieved from https://www.researchgate.net/profile/Rebeca_Jasso-Aguilar/publication/222347193_Sources_Methods_and_Tri angulation_in_Needs_Analysis_A_Critical_Perspective_in_a_Case_Study_of_Waikiki_Hotel_Maids

Marshall, K. (2013). Puppetry in Dementia Care: Connecting through Creativity and Joy, London: Kingsley Publishers.

Martinez-Lirola, M., \& Rubio, F. (2009). Students' beliefs about portfolio evaluation and its influence on their learning outcomes to develop EFL in a Spanish context. International Journal of English Studies, 9/1: Teaching and learning EFL in Spanish speaking contexts.

McAdamis, S. (2001). Teachers tailor their instruction to meet a variety of student needs. Journal of Staff Development, $22(2), 1-5$.

McDonald, E. (2011). Student Portfolios as an Assessment Tool. Retrieved from http://www.educationworld.com/a_curr/columnists/mcdonald/mcdonald025.shtml

Mehregan, M. (2014). Game-based tasks for foreign language instruction: Perspectives on young learners' vocabulary acquisition. The IAFOR Journal of Language Learning, 1(1), 1-12. https://doi.org/10.22492/ijll.1.1.03

Nassirdoost, P., \& Mall, A. B. (2015). The impact of portfolio assessment on EFL learners' vocabulary achievement and motivation. Journal of the Study of English Linguistics, 3(1). https://doi.org/10.5296/jsel.v3i1.7750

Nikolaou, G. (2008). Educative policies for the cultural diversity management in Greece and Europe, at Mavroskoufis, D. (edit.), Edification Guide: Intercultural education and culture. AUTH, EPPAS, Thesssaloniki. (translated from Greek).

Nova-Kaltsouni, C. (2004). The gypsy family in the Greek society, Athens: Greek Ministry of Education, Research and Religious Affairs, University of Athens. (translated from Greek).

Nunan, D. (1988). The Learner-Centered Curriculum: A study in second language teaching, Cambridge: Cambridge University Press. https://doi.org/10.1017/CBO9781139524506 
Peck, S. (2005). Puppet Power: A discussion of how puppetry supports and enhances Reading instruction, pp.73-81. In Bernier, M. \& O'Hare, O. (Eds.), Puppetry in Education: Unlocking Doors to the Mind and Heart: Author House, USA.

Piercy, K. (2004). Analysis of Semi-Structured Interview Data. Utah State University. Retrieved from https://docplayer.net/13806485-Analysis-of-semi-structured-interview-data-kathleen-w-piercy-utah-state-univer sity-1.html

Ploumidi, E. (2016). School failure and school abandonment by Roma: Studying the Attitude of Roma Populations towards Education, Hellenic Institute of Applied Pedagogy and Education. Retrieved from

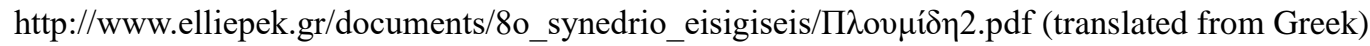

Raines, T., Hess, R., Barrett, C., A’Vant, E., Nazer, S, Scherr, T., Wille, A., \& Baas, S. (2016). Supporting Refugee Children and Youth: Tips for Educators. Retrieved from

https://www.nasponline.org/resources-and-publications/resources-and-podcasts/diversity/social-justice/supporti ng-marginalized-students-in-stressful-times-tips-for-educators

Reeves, T. C. (2000). Alternative Assessment Approaches for Online Learning Environments in Higher Education, Educational Computing Research, 3(1), 101-111. https://doi.org/10.2190/GYMQ-78FA-WMTX-J06C

Richards, J. C. (2001). Curriculum Development in Language Teaching. New York: Cambridge University Press. https://doi.org/10.1017/CBO9780511667220

Robson, C. (2005). Real World Research. Oxford: Blackwell Publishing. Retrieved from http://www.dem.fmed.uc.pt/Bibliografia/Livros_Educacao_Medica/Livro34.pdf

Ryan, R., \& Deci, E. (2000). Self determination theory and the facilitation of intrinsic motivation, social development, and well being. American Psychologist, 55, 68-78. https://doi.org/10.1037/0003-066X.55.1.68

Santangelo, T., \& Tomlinson, C. A. (2012). Teacher educators' perceptions and use of Differentiated instruction practices: An exploratory investigation. Action in Teacher Education, 37(4), 309-27. https://doi.org/10.1080/01626620.2012.717032

Savignon, S. (2017). Communicative Competence. https://doi.org/10.1002/9781118784235.eelt0047

Scott, A., \& Ytreberg, L. (1990). Teaching English to Children. London: Longman. Retrieved from http://www.cje.ids.czest.pl/biblioteka/6940128-Teaching-English-To-Children.pdf

Shabiralyani, G., Shahzad Hasan, K., Hamad, N., \& Iqbal, N. (2015). Impact on visual Aids in Enhancing the Learning Process Case Research: District Dera Ghazi Khan, Journal of Education and Practise, 6(19), $226-234$. Retrieved from https://files.eric.ed.gov/fulltext/EJ1079541.pdf

Sougari, A., \& Sifakis, N. (2007). Teacher roles and learners' motivation - a preliminary investigation of Greek state-school EFL teachers'viewpoints. Retrieved from http://www.enl.auth.gr/symposium/vol_II/28b.pdf

Task Based Learning. (2009). Pools-M. Retrieved from https://www.languages.dk/archive/pools-m/manuals/TBL.pdf

Taylor, P. E. (1998). Questionnaire design: Asking questions with a purpose. Program Development and Evaluation, University of Wisconsin- Extension, Cooperative Extension.

Tomlinson, C. A. (1999). The Differentiated Classroom: Responding to the Needs of All Learners. Alexandria: ASCD.

Tomlinson, C. A. (2001). How to differentiate instruction in mixed-ability classrooms (2nd ed.). Alexandria: Association for Supervision and Curriculum Development.

Tomlinson, C. A. (2005).Grading and differentiation: Paradox or good practice? Theory into Practice, 44(3), $262-269$. https://doi.org/10.1207/s15430421tip4403_11

Tomlinson, C. A. (2014). The Differentiated Classroom: Responding to the Needs of all Learners. Alexandria: Association for Supervision and Curriculum Development. Retrieved from

http://www.ascd.org/ASCD/pdf/siteASCD/publications/books/differentiated-classroom2nd-sample-chapters.pdf

Tomlinson, C. A., \& Strictland, C. A. (2005). Differentiation in Practice Grades 9-12: A Resource Guide for Differentiating Curriculum. Alexandria, VA: ASCD.

Trilianos, A. (2006). Education of Repatriated and Foreign Students in Greece, Paedagogic Theory and Practice Issue 1, 38-45. Retrieved from http://kesy.dra.sch.gr/images/pdfs/h_ekpsh_tvn_palin.pdf (translated from 
Greek).

Tsagari, C., \& West, R. (2004). Testing and Assessment in Language Learning: Assessing Students without Tests. Patras: Hellenic Open University.

Tuksinvarajan, A., \&Todd, R. (2009). The E-pet: Enhancing Motivation in E-portfolios, English Teaching Forum, 1, 22-31. Retrieved from https://files.eric.ed.gov/fulltext/EJ923726.pdf

Tzotzou, M. (2014). Designing and administering a needs analysis survey to primary school learners about EFL learning: A case study, Preschool \& Primary Education, 2(1), 59-82. https://doi.org/10.12681/ppej.62

UNESCO. (1995). Our Creative Diversity: Report of the World Commission on Culture and Development. Retrieved from https://unesdoc.unesco.org/ark:/48223/pf0000101651

Van Teijlingen, E. (2014). Semi-structured Interviews, Bournemouth University.

Vasileiadou, I., \& Zafiri, M. (2017). Using Online Computer Games in the ELT Classroom: A Case Study. English Language Teaching, 10(12), 134-150. https://doi.org/10.5539/elt.v10n12p134

Vasileiadou, M., \& Pavli-Korre, M. (2011). Education of Gypsies in Greece. Retrieved from

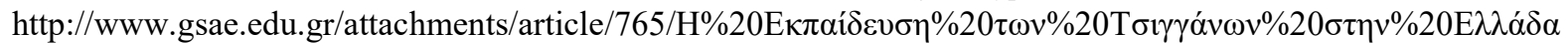
.pdf (translated from Greek)

Vogt, K., \& Froehlich, V., Tsagari D., Csepes, I., Fekete, A., Green, A., .. Kordia, S. (2018). Handbook of Assessment for Language Teachers. TALE Project EU. Retrieved from http://taleproject.eu/pluginfile.php/2129/mod_page/content/12/TALE\%20Handbook\%20-\%20colour.pdf

Wanja, N. M. (2014). Teachers' perspective towards Differentiated Instruction Approach in teaching and learning of mathematics in Kenya. International Journal of Humanities and Social Science, 4(13), 236-241. Retrieved from http://www.ijhssnet.com/journals/Vol_4_No_13_November_2014/28.pdf

Ziomas, D., Bounzas, N., \& Spyropoulou, N. (2011). Greece. Promoting the social Inclusion of Roma .A Study of National Policies, Institute of Social Policy and National Centre for Social Research-EKKE, pp.1-29.

\section{Copyrights}

Copyright for this article is retained by the author(s), with first publication rights granted to the journal.

This is an open-access article distributed under the terms and conditions of the Creative Commons Attribution license (http://creativecommons.org/licenses/by/4.0/). 